\title{
Influence of Alloying Elements on Properties of Ni-Ti-X5 Alloys Consolidated by Spark Plasma Sintering
}

Pavel Salvetr, Andrea Školáková, Filip Průša, Pavel Novák

University of Chemistry and Technology, Department of Metals and Corrosion Engineering, Technicka 5, 16628 Prague

6, Czech Republic, Email: salvetrp@vscht.cz, skolakoa@vscht.cz,prusaf@vscht.cz,Paja.Novak@vscht.cz

This paper deals with the preparation of highly dense Ni-Ti alloys with addition of alloying elements like iron, vanadium and zirconium. The alloying elements were added in an amount of $5 \mathrm{wt}$. \% into Ni-Ti46 wt. \% powder mixture. The prealloyed NiTiX5 powder was prepared by the self-propagating high-temperature synthesis with following milling of the product. The prealloyed powder was consolidated by spark plasma sintering. The microstructures, mechanical properties and abrasive wear of prepared alloys were investigated. The results were compared with Ni-Ti and NiTiX alloys and other materials prepared by powder metallurgy. The undesirable changes in microstructures (formation of the $\mathrm{Ti}_{2} \mathrm{Ni}$ and $\mathrm{Ni}_{3} \mathrm{Ti}$ phases), the increase of hardness and abrasive wear resistance were found during milling and spark plasma sintering.

Keywords: Powder metallurgy, spark plasma sintering, Ni-Ti alloy, mechanical properties, wear resistance

\section{Acknowledgement}

This research was supported by Czech Science Foundation, project No. P108/12/G043 and specific university research (MSMT No 20-SVV/2017).

\section{References}

[1] DUERIG, T., PELTON, A., TREPANIER, CH. (2011). Nitinol - PART I Mechanism and Behaviour, In: SMST eElastic newsletter, ASM International.

[2] JABUR, A.S., AL-HAIDARY, J.T., AL-HASANI, E.S. (2013). Characterization of Ni-Ti shape memory alloys prepared by powder metallurgy. In: Journal of Alloys and Compounds, Vol. 578, pp. 136-142.

[3] SINA, H., SURREDDI, K.B., IYENGAR, S. (2016). Phase evolution during the reactive sintering of ternary AlNi-Ti powder compacts. In: Journal of Alloys and Compounds, Vol. 661, pp. 294-305.

[4] ŠKOlÁKOVÁ, A., NOVÁK, P., SAlVETR, P., MORAVEC, H., ŠEFL, V., DEDUYTSCHE, D., DETAVERNIER, C. (2017). Investigation of the effect of magnesium on the microstructure and mechanical properties of NiTi shape memory alloy prepared by self-propagating high-temperature synthesis. In: Metallurgical and Materials Transactions A, Vol. 48, pp. 3559-3569.

[5] ELAHINIA, M.H., HASHEMI M., TABESH, M., BHADURI, S.B. (2012). Manufacturing and processing of NiTi implants: A review. In: Progress in Materials Science, Vol. 57, pp. 911-946.

[6] NOVÁK, P., MEJZLÍKOVÁ, L., MICHALCOVÁ, A., ČAPEK, J., BERAN, P., VOJTĚCH, D. (2013). Effect of SHS conditions on microstructure of NiTi shape memory alloy. In: Intermetallics, Vol. 42, pp. 85-91.

[7] WHITNEY, M., CORBIN, S.F., GORBET, R.B. (2008). Investigation of the mechanisms of reactive sintering and combustion synthesis of NiTi using differential scanning calorimetry and microstructural analysis. In: Acta Materialia, Vol. 56, pp. 559-570.

[8] NOVÁK, P., MICHALCOVÁ, A., ŠERÁK, J., VOJTĚCH, D., FABIÁN, T., RANDÁKOVÁ, S., PRŮŠA, F., KNOTEK, V., NOVÁK, M. (2009). Preparation of Ti-Al-Si alloys by reactive sintering. In: Journal of Alloys and Compounds, Vol. 470, pp. 123-126.

[9] PRŮŠA, F., VOJTĚCH, D., BLÁHOVÁ, M., MICHALCOVÁ, A., KUBATÍK, T.F., ČIZŽEK, J. (2015). Structure and mechanical properties of $\mathrm{Al}-\mathrm{Si}-\mathrm{Fe}$ alloys prepared by short-term mechanical alloying and spark plasma sintering. In: Materials \& Design, Vol. 75, pp. 65-75.

[10] NOVÁK, P., MORAVEC, H., SALVETR, P., PRŮŠA, F., DRAHOKOUPIL, J., KOPEČEK, J., KARLÍK, M., KUBATÍK, T.F. (2015). Preparation of nitinol by non-conventional powder metallurgy techniques. In: Materials Science and Technology, Vol. 31, pp. 1886-1893.

[11] LIU, B., HUANG, S., CHEN, L., VAN HUMBEECK, J., VLEUGELS, J. (2017). Rapid synthesis of dense NiTi alloy through spark plasma sintering of a TiH2/Ni powder mixture. In: Materials Letters, Vol. 191, pp. 89-92. 
[12] NOVÁK, P., PRŮŠA, F., ŠERÁK, J., VOJTĚCH, D., MICHALCOVÁ, A. (2010). High-temperature behaviour of Ti-Al-Si alloys produced by reactive sintering. In: Journal of Alloys and Compounds, Vol. 504, pp. 320-324.

[13] NOVÁK, P. (2012). Příprava, vlastnosti a použití intermetalických sloučenin. In: Chemické Listy, Vol. 106, pp. 884-889.

[14] WHITNEY, M., CORBIN, S.F., GORBET, R.B. (2009). Investigation of the influence of Ni powder size on microstructural evolution and the thermal explosion combustion synthesis of NiTi. In: Intermetallics, Vol. 17, pp. 894-906.

[15] NOVÁK, P., VESELÝ, T., MAREK, I., DVOŘÁK, P., VOJTĚCH, V., SALVETR, P., KARLÍK, M., HAUŠILD, P., KOPEČEK, J. (2016). Effect of Particle Size of Titanium and Nickel on the Synthesis of NiTi by TE-SHS. In: Metallurgical and Materials Transactions B, Vol. 47, pp. 932-938.

[16] ZHANG, Z.-H., LIU, Z.-F., LU, J.-F., SHEN, X.-B., WANG, F.-C., WANG, Y.-D. (2014). The sintering mechanism in spark plasma sintering - Proof of the occurrence of spark discharge. In: Scripta Materialia, Vol. 81, pp. 56-59.

[17] NOVÁK, P., ŠKOLÁKOVÁ, A., PIGNOL, D., PRŮŠA, F., SALVETR, P., KUBATÍK, T.F., PERRIERE, L., KARLÍK, M. (2016). Finding the energy source for self-propagating high-temperature synthesis production of NiTi shape memory alloy. In: Materials Chemistry and Physics, Vol. 181, pp. 295-300.

[18] SURYANARAYANA, C. (2001). Mechanical alloying and milling. In: Progress in Materials Science, Vol. 46, pp. 1-184.

[19] NOVÁK, P., VOJTĚCH, D., ŠERÁK, J. (2006). Wear and corrosion resistance of a plasma-nitrided PM tool steel alloyed with niobium. In: Surface and Coatings Technology, Vol. 200, pp. 5229-5236.

[20] SALVETR, P., KUBATIK, T.F., NOVÁK, P. (2016). Preparation of Ni-Ti shape memory alloy by spark plasma sintering method. In: Manufacturing Technology, Vol. 16, pp. 804-808.

[21] SALVETR, P., NOVÁK, P., MORAVEC, H. (2015). Ni-Ti alloys produced by powder metallurgy. In: Manufacturing Technology, Vol. 15, pp. 689-694.

[22] ŠKOLÁKOVÁ, A., NOVÁK, P., SALVETR, P. (2016). Influence of elements with high affinity to oxygen on microstructure and phase composition of Ni-Ti alloy. In: Manufacturing Technology, Vol. 16, pp. 808-814.

[23] SALVETR, P., ŠKOLÁKOVÁ, A., NOVÁK, P. (2016). Changes in microstructure and properties of ni-ti alloy after addition of ternary alloying element. In: Manufacturing Technology, Vol. 16, pp. 1359-1363.

[24] KRISTIANOVÁ, E., NOVÁK, P. (2016). Composite materials NiTi-Ti2Ni, In: Manufacturing Technology, Vol. 16, pp. 961-965.

[25] NOVÁK, P., MAREK, I., MEJZLÍKOVÁ, L., MICHALCOVÁ, A., VOJTĚCH, D. (2012). Reactive-sintering production of intermetallics. In: Materials and Technology, Vol. 46, pp. 559-562. 